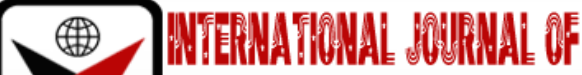

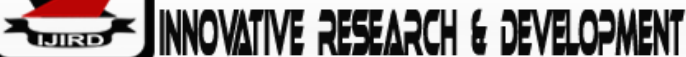

ISSN 2278-0211 (Online)

\section{Design and Construction of an IoT Solar Dryer for Semi-Dried Jerky}

Viet-Duc Ngo
Researcher, Department of Division of Computational Mechatronics,
Hoang-Thinh Do
Institute for Computational Science, Ton DucThang University, Ho Chi Minh City, Vietnam
Researcher, Department of Division of Computational Mechatronics,
Thuy-Van T. Duong
Institute for Computational Science, Ton DucThang University, Ho Chi Minh City, Vietnam
Director, Center of Applied Information Technology,
Ton DucThang University, Ho Chi Minh City, Vietnam
Minh-Duc Tran
Researcher, Division of Computational Mechatronics,
Sy-Dung Nguyen
Researcher, Division of Computational Mechatronics,
Institute for Computational Science, Ton DucThang University, Ho Chi Minh City, Vietnam
Duy-Hien Tong
Institute for Computational Science, Ton DucThang University, Ho Chi Minh City, Vietnam
Reser, Division of Computational Mechatronics,
Thistitute for Computational Science, Ton DucThang University, Ho Chi Minh City, Vietnam
Lecturer, Department of Environgental Science,
Vietnam National University Ho Chi Minh VàoTh 6, Vietnam

\begin{abstract}
:
This paper presents the design, construction of an IoT greenhouse solar dryer for semi-dried jerky. In the dryer, the heated air is controlled automatically by an IoT based system, and at the same time, the greenhouse absorbs solar energy directly through the polycarbonate transparent walls and roof. The results showed that the greenhouse solar dryer was a good dryer for semi-dried jerky. The semi-dried jerky after drying into the dryer was ensured for food safety with non-detected of total aerobic organisms, heavy metal, bacteria. The performance of the greenhouse solar dryer was test and temperature and humidity of drying process were collected through an IoT system.
\end{abstract}

Keywords: Semi-dried jerky, solar dryer, food preservation, greenhouse dryer

\section{Introduction}

Drying is a simple process of removing excess water content from an agricultural product to improve its shelf life by preventing bacterial growth $[1,2]$. Solar dryers are specialized devices that control the drying process and protect agricultural products from damage by insect pests, dust and rain. Nowadays, mixed mode solar dryers have been widely used. In the active mode of mixed solar dryers, a blower or fan is installed to force the heated air into or out of the drying chamber or trays [3].

Wazed et al. [4] designed and fabricated a solar air heater using locally available cheaper material. They concluded that the maximum temperature obtained was $45.5 \square$ in forced circulation with the ambient temperature of $33.25 \square$. A forced/natural convection solar vegetable dryer was designed and constructed for food preservation in a Babagana's study [5]. The results showed that the forced convection system was higher airflow and capabilities compared to the natural convection system. A mixed-mode solar dryer was developed in which the grains are dried simultaneously by both direct radiation through the transparent walls and roof of the cabinet and by the heated air from the solar collector [6]. They found that the temperature rise inside the drying cabinet was up to $74 \%$ for about three hours. The percentage of moisture removed was $85.4 \%$. In a study of Gupta et al. [7], they also concluded that the solar dryer expressed sufficient ability to dry agricultural produce most especially food items to an appreciably reduced moisture level. The storing of energy in latent heat storing materials was very useful because it stored maximum amount energy as compared to sensible heat 
storing materials at equal quantity of material [8]. Solar energy sources were important due to higher prices and shortages of fossil fuels and to reduce the fuel consumption used in the drying process [9]. A developed solar dryer reduced the drying time with a quality product, so it is more efficient than open sun drying.

A considerable amount of research has been conducted to design and construct greenhouse solar dryer [2,10,11]. However, a similar approach has been limited to apply an IoT system for semi-dried jerky. In the present study, an IoT greenhouse solar dryer was designed and constructed using polycarbonate plate. The performance of the dryer was also investigated under natural and forced convection mode of drying.

\section{Materials and Methods}

\subsection{Design Consideration}

Greenhouse solar dryer consists of steel frame, a heated fan, a rotary tray, convection fan, IoT system. Figure 1 shows the schematic view of the greenhouse solar dryer. The minimum temperature for drying jerky is $40 \square$ and the maximum temperature is $70 \square$. The drying temperature could be set up through IoT controller. The drying mode could be switch between manual mode and auto mode. In the manual mode, drying temperature and rotary mode of drying trays were controlled manually through mobile app. In the auto mode, after setting up the drying temperature, the drying trays will rotate automatically with the actuator on/off of $30 \mathrm{~s} / 30 \mathrm{~m}$. The collected data were stored by Excel file and sent to manager's email.

The following materials were used for the construction of the greenhouse solar dryer:

- Steel square tube - The casing (housing) of the entire system, stainless steel is selected.

- Solar collector - Polycarbonate plate is the good option for solar collector that heats the air and airflow system.

- Drying trays - The drying trays are contained inside the greenhouse and were constructed from a double layer of fine chicken wire mesh with a fairly open structure to allow drying air to pass through jerky. The drying trays were also built from stainless steel.

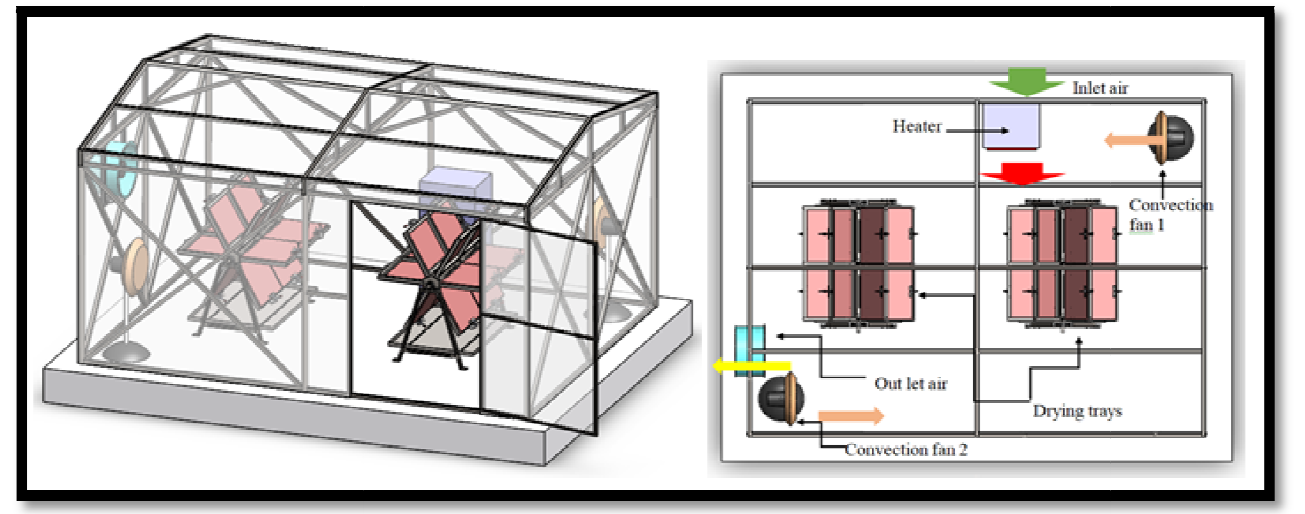

Figure 1: Schematic Views of the Greenhouse Solar Dryer: 3D View (Top) and Top View (Bottom)

\subsection{Design Calculation}

To carry out design calculations, the conditions and assumptions summarized in Table 1 are used for the design of the jerky dryer.

\begin{tabular}{|c|c|}
\hline Items & Condition or Assumption \\
\hline Location & Gialai province, Vietnam \\
\hline Material & Beef \\
\hline Drying per batch, loading rate $\left(\mathrm{m}_{\mathrm{p}}\right)$ & $100 \mathrm{~kg}$ fresh beef \\
\hline Initial moisture content, $\mathrm{M}_{\mathrm{i}}$ & $90 \%$ \\
\hline Final moisture content, $\mathrm{M}_{\mathrm{f}}$ & $65 \%$ \\
\hline Ambient air temperature, $\mathrm{T}_{\mathrm{ab}}$ & $37 \square$ (average) \\
\hline Ambient relative humidity, $\mathrm{RH}_{\mathrm{ab}}$ & $70 \%$ (average) \\
\hline Maximum allowable temperature, $\mathrm{T}_{\max }$ & 70 \\
\hline Drying time, $\mathrm{t}_{\mathrm{d}}$ & 3 hours (average) \\
\hline Incident solar radiation, $\mathrm{I}$ & $20 \mathrm{M} / \mathrm{m}^{2} /$ day (average) \\
\hline Collector efficiency, $\mathrm{\eta}$ & $75 \%$ \\
\hline Wind speed & $2 \mathrm{~m} / \mathrm{s}$ \\
\hline Thickness of sliced beef & $15 \mathrm{~mm}$ \\
\hline Collector area & $14.7 \mathrm{~m}^{2}$ \\
\hline Table 1: Design Conditions and & Assumptions $[1,2,4]$ \\
\hline
\end{tabular}

From the conditions and assumptions in Table 1, the values of the design parameters were calculated. The values were calculated by the following equation: 
+ The amount of moisture to be removed from the product:

$\mathrm{m}_{\mathrm{W}}=\mathrm{m}_{\mathrm{p}}\left(\mathrm{M}_{\mathrm{i}}-\mathrm{M}_{\mathrm{f}}\right) /\left(100-\mathrm{M}_{\mathrm{f}}\right)$

+ Energy required for evaporating water from product:

$\mathrm{E}_{\mathrm{p}}=\mathrm{m}_{\mathrm{w}} \times \mathrm{L}_{\mathrm{v}}$

+ Energy gain by air from Radiation:

$$
\mathrm{Ea}=\mathrm{I}_{\mathrm{c}} \mathrm{A}_{\mathrm{c}} \eta_{\mathrm{c}}
$$

+ Mass flow rate of air:

$\mathrm{Ma}=\left(\mathrm{I}_{\mathrm{c}} \mathrm{A}_{\mathrm{c}} \eta_{\mathrm{c}}\right) /\left(\mathrm{Cp}_{\mathrm{a}} \Delta \mathrm{T}\right)$

+ Average drying rate:

$$
\mathrm{M}_{\mathrm{dr}}=\mathrm{m}_{\mathrm{W}} / \mathrm{t}_{\mathrm{d}}
$$

\section{Results and Discussion}

Figure 2 shows the greenhouse drying solar dryer for semi-dried jerky. The greenhouse was constructed by steel square tube and polycarbonate plate. The drying trays were constructed by stainless steel 304 with a double layer of fine chicken wire mesh.

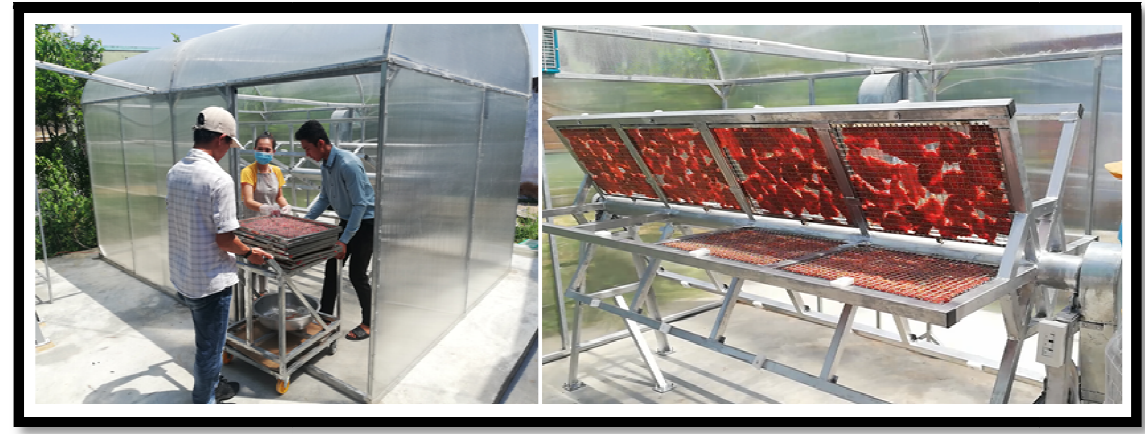

Figure 2: Greenhouse Solar Dryer for Semi-Dried Jerky

To test the dryer performance, $20 \mathrm{~kg}$ fresh beef was load into the drying trays. The time to dry was 3 hours. The initial moisture content of fresh beef was $90 \%$ and the final moisture content was around 66.5\%. Figure 3. shows the platform of the IoT controller. In the platform, we can control the actuator on/off of the heater, the rotate trays, convection fan, and light. Temperature and humidity inside the greenhouse solar dryer were also display in the platform. Temperature of drying process was set up before drying. After setting up the drying temperature, equipment in the greenhouse solar dryer will automatic performance.

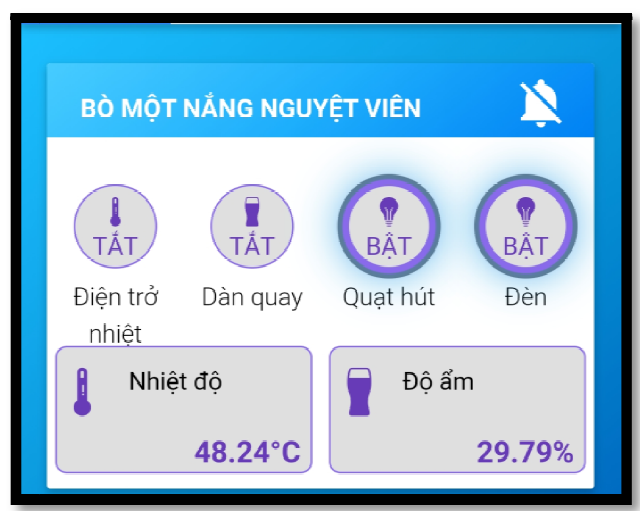

Figure 3: Platform of Iot Controller System

Temperature of drying process was maintained by convection fan and heater. Temperature and humidity of the greenhouse solar dryer in drying process were collected through an IoT system. The results of drying process' parameters were shown in Figure 4 . The average temperature was $56.37 \pm 5.99^{\circ} \mathrm{Cand}$ the average humidity was $31.07 \pm 2.16 \%$. The integration time to collect the data was 10 minutes. 


\begin{tabular}{|c|c|c|c|}
\hline ate & Time & $\mathrm{T}$ & $\mathrm{H}$ \\
\hline Monday, November 9, 2020 & 10:00:00 AM & 48 & 29.5 \\
\hline Monday, November 9,2020 & 10:10:00 AM & 49 & 32.3 \\
\hline Monday, November 9, 2020 & 10:20:00 AM & 49 & 33.1 \\
\hline Monday, November 9, 2020 & 10:30:00 AM & 50 & 32.9 \\
\hline Monday, November 9, 2020 & 10:40:00 AM & 50 & 33.7 \\
\hline Monday, November 9, 2020 & 10:50:00 AM & 51 & 34.5 \\
\hline Monday, November 9, 2020 & 11:00:00 AM & 52 & 33.3 \\
\hline Monday, November 9, 2020 & 11:10:00 AM & 54 & 32.1 \\
\hline Monday, November 9, 2020 & $11: 20: 00 \mathrm{AM}$ & 55 & 32.9 \\
\hline Monday, November 9, 2020 & 11:30:00 AM & 56 & 31.7 \\
\hline Monday, November 9, 2020 & 11:40:00 AM & 58 & 31.5 \\
\hline Monday, November 9, 2020 & 11:50:00 AM & 59 & 31.3 \\
\hline Monday, November 9, 2020 & 12:00:00 PM & 60 & 30.1 \\
\hline Monday, November 9, 2020 & 12:10:00 PM & 61 & 29.9 \\
\hline Monday, November 9, 2020 & $12: 20: 00 \mathrm{PM}$ & 62 & 29.7 \\
\hline Monday, November 9, 2020 & 12:30:00 PM & 63 & 28.5 \\
\hline Monday, November 9, 2020 & 12:40:00 PM & 63 & 28.3 \\
\hline Monday, November 9, 2020 & $12: 50: 00 \mathrm{PM}$ & 65 & 27.1 \\
\hline Monday, November 9, 2020 & 1:00:00 PM & 66 & 27.9 \\
\hline
\end{tabular}

Table2

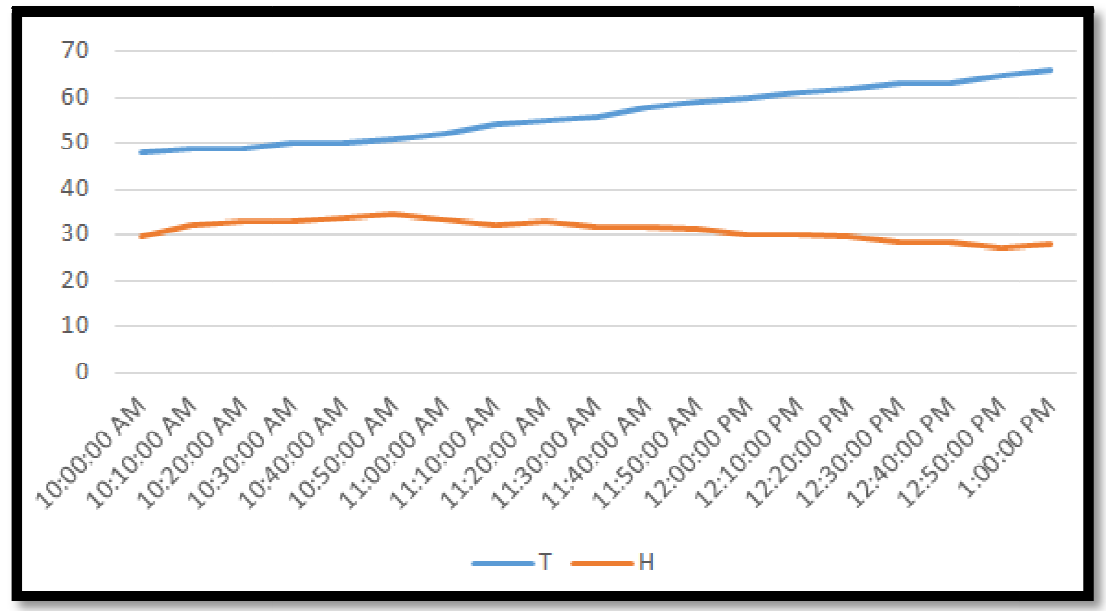

Figure 3: Collected Temperature and Humidity of the Greenhouse Solar Dryer

Figure 4 shows the semi-dried jerky after drying in the IoT solar dryer. The color of semi-dried jerky was still bright red. The texture of the meat was still firm. The texture of the meat back to normal when pressed. Because of dried beef, there was no the blood-like red liquid flowing out of the meat. The surface of the meat was smooth and no viscosity. The humidity of meat was $66.5 \%$ which is the best humidity for storing in the freezer.

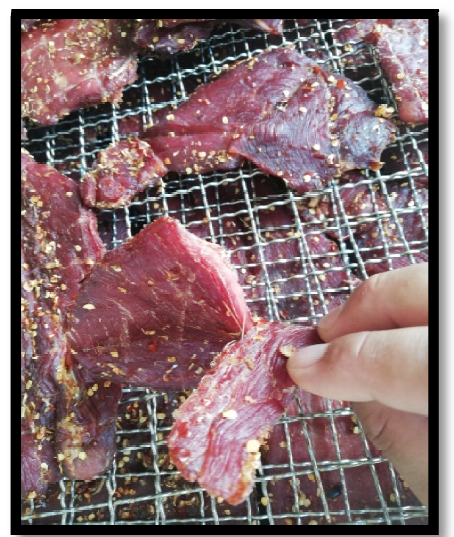

Figure 4: Semi-Dried Jerky after Drying in the Iot Solar Dryer 
After drying beef, the sample was transfer to chemical laboratory and biological laboratory for further test. We test several parameters for semi-dried jerky such as total bacteria, $\mathrm{pH}$, humidity of the product, total heavy metal. The testing results were summarized in Table 3. As shown in Table 2, some bacteria such as staphylococcus aureus, clostridium perfringens, listeria monocytogenes, and E. coli were non-detected. The $\mathrm{pH}$ of semi-dried jerky was $5.6 \pm 0.06$. We concluded that semi-dried jerky was ensured for food safety after drying with the greenhouse solar dryer.

\begin{tabular}{|c|c|}
\hline Parameters & Result \\
\hline Staphylococcus aureus & Non-detected \\
\hline Clostridium perfringens & Non-detected \\
\hline Listeria monocytogenes & Non-detected \\
\hline Salmonella & Non-detected \\
\hline Cadimi (Cd) & $0.0058 \pm 0.0001$ \\
\hline Coliforms (CFU/g) & $3.0 \times 10^{1}$ \\
\hline E. coli & Non-detected \\
\hline Total aerobic organisms & $5.85 \times 10^{2} \pm 3.85 \times 10^{2}$ \\
\hline Lead (Pb) & Non-detected \\
\hline pH & $5.6 \pm 0.06$ \\
\hline Humidity (\%) & 66.5 \\
\hline Table 3: Testing report of Semi-Dried Jerky
\end{tabular}

\section{Conclusion}

In this work, a greenhouse solar dryer has been designed and constructed for the drying of semi-dried jerky. An IoT system was installed to control and monitor the temperature and humidity and to store the data of drying process. Semi-dried jerky after dried with the greenhouse solar dryer was transferred to chemical and biological labs for further test. The results showed that semi-dried jerky was ensured for food safety with no bacteria, heavy metal, and total aerobic organisms. Temperature of drying process was maintained by the heater and convection fan through the IoT controller system. The suitable time to dry jerky was 3 hours and the drying temperature was $55 \square$.

The greenhouse solar dryer developed in this work will allow to research and improve the quality of the dried agricultural products. The dryer will also suitable for other agricultural products and agro-industrial waste.

\section{Acknowledgement}

This research is funded by People's Committee of Gia Lai province under grant number KHGL-02-18. This work was supported by Gialai Department of Science and Technology, and Ton DucThang University, Ho Chi Minh City, Vietnam.

\section{References}

i. Hegde, V. N., Hosur, V. S., Rathod, S. K., Harsoor, P. A., \& Narayana, K. B. (2015). Design, fabrication and performance evaluation of solar dryer for banana. Energy, Sustainability and Society, 5(1), 23. https://doi.org/10.1186/s13705-015-0052-x

ii. Tiwari, S., Tiwari, G. N., \& Al-Helal, I. M. (2016). Development and recent trends in greenhouse dryer: A review. Renewable and Sustainable Energy Reviews, 65, 1048-1064. https://doi.org/10.1016/j.rser.2016.07.070

iii. Ngo, V.-D., Do, H. T., T. Duong, T. V., Tran, M. D., Nguyen, S. D., Tong, D. H., \& Duong, T. B. H. (2020). Quality Standards and Inexpensive Drying Technology for Semi-Dried Jerky in Gialai Province: A Short Review. International Journal of Innovative Research \& Development, 9(11), 10.

iv. Wazed, M. A., Nukman, Y., \& Islam, M. T. (2010). Design and fabrication of a cost-effective solar air heater for Bangladesh. Applied Energy, 87(10), 3030-3036. https://doi.org/10.1016/j.apenergy.2010.02.014

v. Babagana, G., \& Silas, K. (2012). Design and construction of forced/natural convection solar vegetable dryer with heat storage. ARPN Journal of Engineering and Applied Sciences, 7(10), 6.

vi. Bolaji, B. O., \&Olalusi, A. P. (2008). Performance Evaluation of a Mixed-Mode Solar Dryer. Technical Report, 7.

vii. Gupta, P. M., Das, A. S., Barai, R. C., Pusadkar, S. C., \&Pawar, V. G. (n.d.). Design and Construction of Solar Dryer for Drying Agricultural Products.04(03), 6.

viii. Papade, C. V., \&Boda, M. A. (2014). Design \& Development of Indirect Type Solar Dryer with Energy Storing Material. International Journal of Innovative Research in Advanced Engineering, 1(12), 6.

ix. Lingayat, A., Chandramohan, V. P., \& Raju, V. R. K. (2017). Design, Development and Performance of Indirect Type Solar Dryer for Banana Drying. Energy Procedia, 109, 409-416. https://doi.org/10.1016/j.egypro.2017.03.041

X. Akoy, E.-A. O. M., Ismail, M. A., Ahmed, E.-F. A., \&Luecke, W. (2004). Design and construction of a solar dryer for mango slices. Most, 1-7.

xi. Montero, I., Blanco, J., Miranda, T., Rojas, S., \&Celma, A. R. (2010). Design, construction and performance testing of a solar dryer for agro-industrial by-products. Energy Conversion and Management, 51(7), 1510-1521. https://doi.org/10.1016/j.enconman.2010.02.009 